\title{
Relationships of pre-inoculation high temperature to root browning caused by Pythium aphanidermatum in hydroponically-grown sweet pepper
}

\author{
Coralie R. Sopher \& John C. Sutton \\ School of Environmental Sciences, University of Guelph, Guelph, Ontario, N1G 2W1, Canada \\ Author for correspondence: John C. Sutton, email: jcsutton@uoguelph.ca
}

\begin{abstract}
Episodes of high root-zone temperature $\left(33^{\circ} \mathrm{C}\right)$ were investigated in relation to susceptibility of sweet pepper to root rot caused by Pythium aphanidermatum. Pepper plants were grown in aerated nutrient solution in hydroponic units positioned in temperature-controlled water baths. Root zone temperature was $23^{\circ} \mathrm{C}$ except during high temperature treatments. Roots were exposed to $33^{\circ} \mathrm{C}$ for 0 to $216 \mathrm{~h}$, inoculated with $P$. aphanidermatum and assesseda at intervals for colonization by the pathogen and for severity of browning (necrosis). The pathogen colonized all roots within $12 \mathrm{~h}$ following inoculation. The roots turned brown earlier when exposed to $33^{\circ} \mathrm{C}$ for more than $9 \mathrm{~h}$ prior to inoculation compared to those exposed for 0 to $6 \mathrm{~h}$. Browning developed progressively earlier as the period at $33^{\circ} \mathrm{C}$ was increased from 9 to $144 \mathrm{~h}$, and was 4 days earlier for exposures of 144 to $216 \mathrm{~h}$ compared to 0 to $9 \mathrm{~h}$. Browning was precocious also when inoculation was delayed as long as $216 \mathrm{~h}$ following exposure at $33^{\circ} \mathrm{C}$ for $72 \mathrm{~h}$. We conclude that high temperature predisposes pepper plants to precocious browning caused by $P$. aphanidermatum and that predisposition lasts for at least 9 days.
\end{abstract}

Keywords: Capsicum annuum, predisposition, stress, root rot.

RESUMO

Relações entre elevadas temperaturas na pré-inoculação e o escurecimento radicular causado por Pythium aphanidermatum em pimentão hidropônico

Episódios de elevada temperatura na zona radicular foram analisados em relação à suscetibilidade de pimentão à podridão radicular causada por Pythium aphanidermatum. As plantas foram cultivadas em solução nutritiva aerada em unidades hidropônicas contidas em caixas com controle da temperatura. A temperatura da zona radicular foi de $23^{\circ} \mathrm{C}$, com exceção dos períodos dos tratamentos com elevada temperatura. As raízes foram expostas a $33^{\circ} \mathrm{C}$ por 0 a $216 \mathrm{~h}$, inoculadas com $P$. aphanidermatum e avaliadas quanto à colonização do patógeno e a severidade do escurecimento (necrose). O patógeno colonizou todas as raízes em $12 \mathrm{~h}$. As raízes escureceram precocemente quando expostas a $33^{\circ} \mathrm{C}$ por mais de $9 \mathrm{~h}$, quando comparadas com raízes expostas por 0 a $6 \mathrm{~h}$. O desenvolvimento de escurecimento precoce foi progressivo quando o período a $33^{\circ} \mathrm{C}$ aumentou de 9 para $144 \mathrm{~h}$ e ocorreu quatro dias antes quando as raízes foram submetidas a temperatura elevada de 144 a $216 \mathrm{~h}$, quando comparadas com 0 a $9 \mathrm{~h}$. O escurecimento precoce também ocorreu quando a inoculação foi realizada por até $216 \mathrm{~h}$ após a exposição a $33^{\circ} \mathrm{C}$ por $72 \mathrm{~h}$. Conclui-se que elevadas temperaturas predispõem plantas de pimentão ao precoce escurecimento radicular causado por $P$. aphanidermatum e que a predisposição se mantém por um período mínimo de nove dias.

Palavras-chave: Capsicum annuum, prédisposição, estresse, podridão radicular, hidroponia.

\section{INTRODUCTION}

Pythium root rot is a major factor limiting the productivity and profitability of hydroponically-grown sweet peppers (Capsicum annuum L.) in Ontario (OwenGoing, 2002; Owen-Going et al., 2003). The disease is characterized by root tip browning, expansive browning of the roots, reduced growth rate of the roots and shoots, and during advanced stages of pathogenesis, wilting and yellowing of the foliage (Owen-Going et al., 2003; Johnstone et al., 2005; Sutton et al., 2006). Pythium aphanidermatum (Edson) Fitzp. is the principal causal agent of root rot, but several other species of Pythium were reported to cause mild root symptoms in hydroponic peppers (Owen-Going et al., 2003). Numerous anecdotal reports by growers, advisory personnel, and our research group leave little doubt that periods of high temperature in hydroponic greenhouses, especially in the root zones of crops, frequently evoke increases in severity of Pythium root rot and serious yield losses in commercial peppers. Temperature of the rootzone is commonly high (e.g. 28 to $35^{\circ} \mathrm{C}$ ) for several hours each day when warm weather prevails and also during cool weather when the rooting media of the crop such as rock wool or coconut fiber (coir) are exposed to direct sunlight (Sutton et al., 2006). Cooling the root zone as a preventative or remedial measure is generally not feasible 
or cost-effective in Ontario greenhouses. Until recently root zones were commonly cooled by introducing fresh nutrient solution prepared with cool water, but this method is no longer practiced because of needs to conserve water resources, minimize fertilizer use, and limit disposal of used solutions into the environment. Nutrient solutions are in some instances oxygenated when root zone temperatures are high because the concentration of dissolved oxygen is often sufficiently low to favor rapid development of root rot associated with $P$. aphanidermatum and other Pythium spp. in peppers and other hosts (Chérif et al., 1997; Zheng et al., 2000; Sutton et al., 2006). Alternative means for controlling root rot in hydroponic peppers include use of biological control organisms, fungicides, and methods to disinfest the nutrient solution (Corrêa \& Bettiol, 2009).

Observations under controlled conditions have confirmed that root rot caused by $P$. aphanidermatum is more severe in peppers and other hosts when the temperature is high compared with cooler conditions (Sutton et al., 2006). In hydroponic peppers, root browning (necrosis) increased slowly or not at all at $18-22^{\circ} \mathrm{C}$ but rapidly at $28-30^{\circ} \mathrm{C}$ (Owen-Going et al., 2008). In chrysanthemums grown in single-plant hydroponic containers with constant root-zone temperatures, rootbrowning increased with temperature from 20 to $32^{\circ} \mathrm{C}$ (Liu et al., 2007). In tomato, spinach, cucumber, soybeans, rye, sugar beets and other hosts, root browning was severe when root-zone temperatures were moderate or high $\left(230-27^{\circ} \mathrm{C}\right.$ or $\left.35^{\circ} \mathrm{C}\right)$, but mild at lower temperatures (Thompson et al., 1971; Van der Plaats-Niterink,1981; Gold \& Stanghellini, 1985; Martin \& Loper, 1999; Panova et al., 2004; Sutton et al. 2006). Under low temperatures (e.g. $15-$ $20^{\circ} \mathrm{C}$ ) inoculated roots may be colonized but symptomless (Littrell \& McCarter, 1970; Sutton et al. 2006). In general, high temperatures reported as favorable for severe root rot were similar to those encountered in the root zone of peppers during warm or hot conditions in commercial greenhouses in Ontario. Enhanced disease severity at higher temperatures may be related in part to increased ability of the pathogen to infect the host and to shifts in interactions between pathogens and other organisms in the root zone (Martin \& Loper, 1999). However, as Martin \& Loper (1999) pointed out, host susceptibility to root rot is also undoubtedly influenced by temperature.

Several authors surmised that the greater severity of Pythium root rot under high temperature conditions is due to responses of the host plants to environmental stress factors (stressors), particularly elevated temperature in the root zone or plant canopy and reduced concentration of dissolved oxygen in the nutrient solution (Sutton et al. 2006). The notion that exposure of plants to environmental stress factors increases host susceptibility to root rot has not been conclusively demonstrated. Clearly, the potential exists for the host and pathogen to respond both independently and interactively to high temperature conditions. In the previous reports, the roles of the host and pathogen in mediating effects of high temperature on root rot could not be differentiated because the pathogen (P. aphanidermatum or other Pythium sp.) was present in the root zone at the time of high temperature treatment. Under conditions in culture, mycelial growth of $P$. aphanidermatum is rapid at $30-40^{\circ} \mathrm{C}$ and relatively slow at $10-25^{\circ} \mathrm{C}$, while zoospore production is abundant at $17-31^{\circ} \mathrm{C}$ but not at $35^{\circ} \mathrm{C}$ or $37^{\circ} \mathrm{C}$ (Van der Plaats-Niterink, 1981; Gold \& Stanghellini, 1985). Regardless of the importance of the pathogen as a mediating factor, a clear and quantitative understanding of the role of the host would be advantageous for predicting and managing Pythium root rot. Effects of high temperature on root rot susceptibility can be investigated and quantified by exposing plants to high temperature episodes before the roots are inoculated with the pathogen, and thereby satisfying the requisite conditions to demonstrate host predisposition to disease (Colhoun, 1979). Predisposition normally refers to an increased susceptibility of plants to disease brought about by environmental factors acting prior to infection by the pathogen (Jarvis, 1992). Quantitative information of the frequency, duration, intensity (in ${ }^{\circ} \mathrm{C}$ ), and time of occurrence of episodes of high root-zone temperature in relation to predisposition of peppers to root colonization by $P$. aphanidermatum and the development of root browning could provide an effective basis for predicting the risk of rapid disease increase and the need for re-mediation measures.

In a preliminary study, it was found that exposure of the roots of healthy pepper plants to high temperature $\left(28-33^{\circ} \mathrm{C}\right)$ for several days immediately prior to inoculation with $P$. aphanidermatum predisposed the plants to increased severity of root rot (Sopher \& Sutton, 2008). The present research was conducted to further investigate high root-zone temperature in relation to predisposition of peppers to Pythium rootrot. The first objective was to quantify relationships between the duration of high root-zone temperature $\left(33^{\circ} \mathrm{C}\right)$ immediately before inoculation and subsequent root colonization by $P$. aphanidermatum and progress of root browning. The second objective was to quantify effects of delayed inoculation following high temperature treatment on the progress of root colonization and browning.

\section{MATERIAL AND METHODS}

\section{Hydroponic pepper plants}

Seeds of sweet pepper (Capsicum annuum) cv. Cubico (DeRuiter Seeds Inc., Columbus, OH, USA) were germinated in rock wool plugs $(2.5 \mathrm{~cm}$ X $2.5 \mathrm{~cm} \mathrm{X} 4.0 \mathrm{~cm}$; Grodan, Roermond, The Netherlands) in plastic trays in a growth room. Plants were watered with de-ionized water during the initial three weeks and with half-strength nutrient solution in the subsequent two weeks. At five weeks after sowing, the pepper plants were transferred to single-plant hydroponic units on a bench in the growth room. Each plant in its rock-wool plug was placed in a $5 \mathrm{~cm}$-diameter mesh pot (Homegrown Hydroponics, Breslau, ON, Canada) positioned in a hole made in the lid of a $475 \mathrm{~mL}$ white polyethylene 
container filled with nutrient solution. To exclude light, the container lids were covered with black-on-white plastic, white side up. The containers were arranged in black plastic trays $(100 \mathrm{~cm} \times 38 \mathrm{~cm} \times 19 \mathrm{~cm}$ deep) on a bench in a growth room. The nutrient solution was prepared with 0.73 $\mathrm{g}$ of soluble fertilizer (NPK, 7:11:27; plus microelements; Plant Products Ltd., Brampton, ON, Canada) and $0.48 \mathrm{~g}$ $\mathrm{Ca}\left(\mathrm{NO}_{3}\right)_{2}$ per liter of de-ionized water, and adjusted to $\mathrm{pH}$ 5.8. The electrical conductivity (EC) was near $1.5 \mathrm{mS} \cdot \mathrm{cm}^{-1}$. The nutrient solution in each unit was continuously aerated by means of aquarium air pumps and plastic tubes $(2 \mathrm{~mm}$ internal diameter) and replenished as needed. The dissolved oxygen content (DOC) of the aerated solutions was monitored with an oxygen meter (model YSI 55, Yellow Springs Instruments Co. Inc., Yellow Springs, OH, USA) and ranged from 5 to $7 \mathrm{mg} \mathrm{O} / \mathrm{L}$ during experiments. The nutrient solution temperature normally equilibrated 0.5 $1.0^{\circ} \mathrm{C}$ below that of the air temperature of the growth room, which was maintained at $23-24^{\circ} \mathrm{C}$. The photoperiod was 16 $\mathrm{h}$ and light was provided by fluorescent tubes (115 W Cool White, GTE, Sylvania Ltd, Canada) supplemented with incandescent bulbs. The intensity of photosynthetically active radiation (PAR) at plant height was 180-200 $\mu \mathrm{mol} /$ $\mathrm{m}^{2} / \mathrm{s}$ as measured by quantum sensors (Q 3991-4 LI-COR Inc., Lincoln, NE). The relative humidity was maintained at $60-65 \%$. Plants were used for experiments when 7- 8 weeks old, 9 - $11 \mathrm{~cm}$ tall and had root systems $8-10 \mathrm{~cm}$ long.

High temperature treatment of roots

Forinvestigations of pre-inoculation hightemperature of the root zone in relation to root rot, temperature-controlled water baths were positioned on a bench beneath light banks in the growth room. Each bath comprised a $37.8 \mathrm{~L}$ plastic tote box with the sides and bottom insulated with foilcovered bubble wrap. Plants in the hydroponic containers were maintained in the baths throughout experiments (Figure 1). Water temperature of unheated baths was near $23^{\circ} \mathrm{C}$. For high temperature treatments the water in each bath was heated to $33^{\circ} \mathrm{C}$ by means of two thermostaticallycontrolled aquarium heaters (model $100 \mathrm{~W}$ Tronic, Rolf C. Hagen, Montreal, QC). Approximately $3 \mathrm{~h}$ was required to raise the temperature of the plant nutrient solution from 23 to $33^{\circ} \mathrm{C}$. Immediately following high root-zone temperature treatments the aquarium heaters were turned off and the water and nutrient solution cooled to $23^{\circ} \mathrm{C}$ during $3-4 \mathrm{~h}$. The temperature of the nutrient solution was measured frequently during experiments using calibrated alcohol-inglass thermometers.

\section{Pythium inoculum and inoculations}

Pythium aphanidermatum isolate P6 from hydroponic cucumber was maintained for up to 12 weeks on roots of living host plants and recovered when needed by incubating pieces of the colonized roots for two days on $\mathrm{P}_{5} \mathrm{AR}$, a Pythium-selective agar medium (Owen-Going et al., 2003). To produce zoospores colonies of the pathogen grown on $20 \%$ V-8 medium in Petri dishes were flooded with sterilized de-ionized water after $48 \mathrm{~h}$ of incubation and again after 96 $\mathrm{h}$ under a critically-controlled temperature regime (OwenGoing et al., 2003). Zoospores released during the second flooding were collected in plastic beakers. Zoospore density in the aqueous suspensions was estimated by vibrating

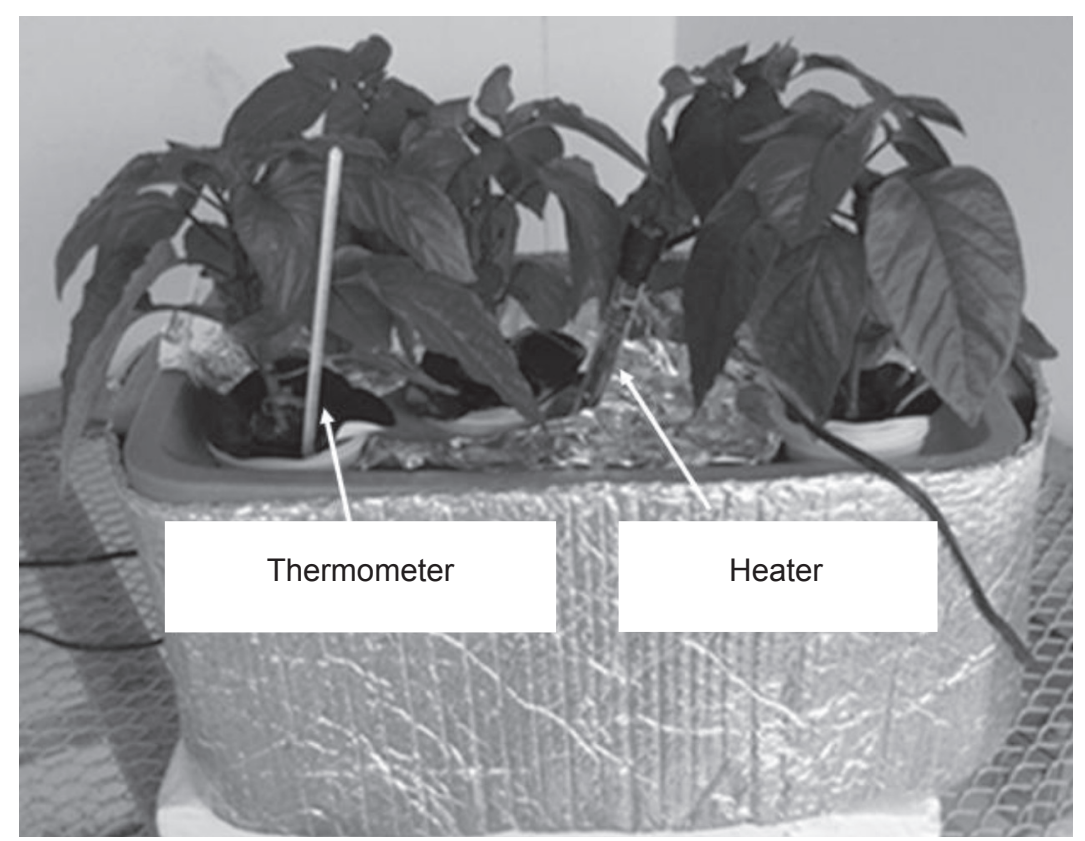

FIGURE 1 - Single-plant hydroponic units with pepper plants in a temperaturecontrolled water bath. 
1-mL samples in microfuge tubes on a Vortex mixer (Fisher Scientific, Toronto, ON, Canada) for $30 \mathrm{~s}$ and counting the immobilized spores on a hemocytometer. For inoculations the suspensions were diluted to $5 \times 10^{3}$ zoospores $\mathrm{mL}^{-1}$ and gently poured into plastic trays. For inoculation, plants were carefully positioned in the trays with all of the roots immersed in the zoospore suspension for $30 \mathrm{~min}$. The plants were returned to their respective hydroponic units immediately after inoculation. Roots of control plants were immersed in sterilized de-ionized water.

\section{Estimation of colonization and discoloration of the roots}

To estimate percent roots colonized by Pythium, 20 principal roots were removed from each plant and cut into 1-cm-long segments. The segments were surfacedisinfested in $1 \% \mathrm{NaOCl}$ for $30 \mathrm{~s}$ and in $70 \%$ ethanol for 30 $\mathrm{s}$, rinsed three times in sterile distilled water and blotted dry. Thirty random segments from each plant were incubated on the $\mathrm{P}_{5} \mathrm{AR}$ selective medium at $25^{\circ} \mathrm{C}$ for 48 $\mathrm{h}$ and assessed for incidence of $P$. aphanidermatum. For estimating root discoloration, each plant was held with the roots above the nutrient solution and its root system was examined for about $15 \mathrm{~s}$ with the aid of a hand lens (10X magnification). The percent of root tips and of total roots that were discolored were estimated using an equalincrement scale of $0-10(0=0 \%, 1=1-10 \%, 2=11-20 \% \ldots$. $10=91-100 \%)$. Discoloration was generally gray-brown or reddish-brown. Mid-point values of scale increments were used for data analysis.

\section{Pre-inoculation high temperature in relation to root rot}

A series of experiments was conducted to examine pre-inoculation episodes of high root-zone temperature in relation to root colonization by $P$. aphanidermatum and root discoloration (browning) after the roots were inoculated with the pathogen. For high temperature treatments the nutrient solution was maintained at $33^{\circ} \mathrm{C}$ for $0,1,3,6,9$, $12,18,24,48,72,96,120,144,168,192$, or 216 h. Roots were inoculated with $P$. aphanidermatum, or not inoculated, within an hour after the nutrient solution of the high temperature treatments had cooled to $23^{\circ} \mathrm{C}$. For logistical reasons, effects of only four or five different periods of high temperature were investigated in any given experiment. The high temperature periods were overlapped among experiments to ascertain consistency of results and to provide a basis to combine data for presentation. Controls included non-inoculated and inoculated plants maintained continuously at $23^{\circ} \mathrm{C}$, and non-inoculated plants exposed to the same high temperature periods as the inoculated plants. High temperature treatments within any given experiment were staggered so that all plants could be inoculated at the same time with the same batch of inoculum. There were three to six replicate plants per treatment and three or four repetitions of each experiment. Root colonization and discoloration were estimated daily.

\section{Delayed inoculation as a factor affecting relationships of pre-inoculation high temperature and root rot}

In a second series of experiments, time of inoculation following a high temperature episode in the root zone was examined as a possible variable influencing the effects of the episode on root colonization by $P$. aphanidermatum and root browning. In a standard high temperature treatment the nutrient solution was maintained at $33^{\circ} \mathrm{C}$ for $72 \mathrm{~h}$. At all other times the solution was kept at $23^{\circ} \mathrm{C}$ except for the time required, respectively, to warm and cool the solution before and after the high temperature treatment. The nutrient solution of other plants was maintained continuously at $23^{\circ} \mathrm{C}$. Plants of each temperature treatment either were not inoculated or were inoculated with $P$. aphanidermatum at $0,24,48,72,96,120,144$, and $216 \mathrm{~h}$ following the high temperature treatment. For logistical reasons, the effects of only four intervals between the high temperature treatment and inoculation were investigated in any given experiment. The interval treatments were overlapped among experiments to ascertain consistency among results and to provide a basis to combine data for presentation. In each experiment plants of each treatment were inoculated at the same time with the same batch of inoculum. In preliminary studies, it was found that the age differences of the plants when inoculated did not significantly affect progress of root browning. Root browning was estimated immediately before and after the high temperature treatment, immediately before the time of inoculation, and daily thereafter.

\section{Experimental design and Statistical analysis}

The experimental unit in all experiments was a single plant in a hydroponic unit. For each treatment water baths were used, each accommodating up to six hydroponic units. Great care was taken to avoid the extreme risk of cross contamination of non-inoculated hydroponic units with $P$. aphanidermatum during all experiments. There were three to five replicate plants per treatment. Each experiment was designed as a randomized complete block and conducted two to four times. The data were analyzed using the ANOVA procedure of SAS software Version 9.1 (SAS Institute Inc. Cary, N.C., USA). The Type 1 error rate $(\propto)$ was set at 0.05 .

\section{RESULTS}

Pre-inoculation high temperature in relation to root rot Pythium aphanidermatum was not recovered from roots of non-inoculated plants. Non-inoculated roots maintained continuously at $23^{\circ} \mathrm{C}\left(0 \mathrm{~h}\right.$ at $\left.33^{\circ} \mathrm{C}\right)$ appeared whitish and exhibited no discoloration throughout the experiment. Non-inoculated roots treated at $33^{\circ} \mathrm{C}$ for up to $72 \mathrm{~h}$ also were symptomless but developed a pale straw color when treated for 96 to $216 \mathrm{~h}$. The pathogen was recovered from all root segments of inoculated plants that were placed on the selective agar medium at $12 \mathrm{~h}$ following inoculation or later, including segments of roots that were not exposed 
Relationships of pre-inoculation high temperature to root browning...

to high temperature. Roots of inoculated plants maintained continuously at $23^{\circ} \mathrm{C}\left(0 \mathrm{~h}\right.$ at $\left.33^{\circ} \mathrm{C}\right)$ were symptomless until 4 days after the roots were inoculated with $P$. aphanidermatum when a few root tips appeared brown. The incidence of brown root tips subsequently increased to $100 \%$ during days 5 to 12 (Figure 2A). Expansive browning of the roots increased rapidly to $100 \%$ during days 6 to 12 after inoculation (Figure 2B). The curves for brown root tips and expansive root browning were similar in form, and each increased in a linear pattern from approximately 5\% severity to total browning.

Disease increase in roots treated at $33^{\circ} \mathrm{C}$ for 1,3 , or $6 \mathrm{~h}$ prior to inoculation with $P$. aphanidermatum did not differ significantly from increases observed in roots of the inoculated plants that were not treated at high temperature (i.e. $0 \mathrm{~h}$ at $33^{\circ} \mathrm{C}$, data not shown). This was true whether disease was assessed as brown root tips or

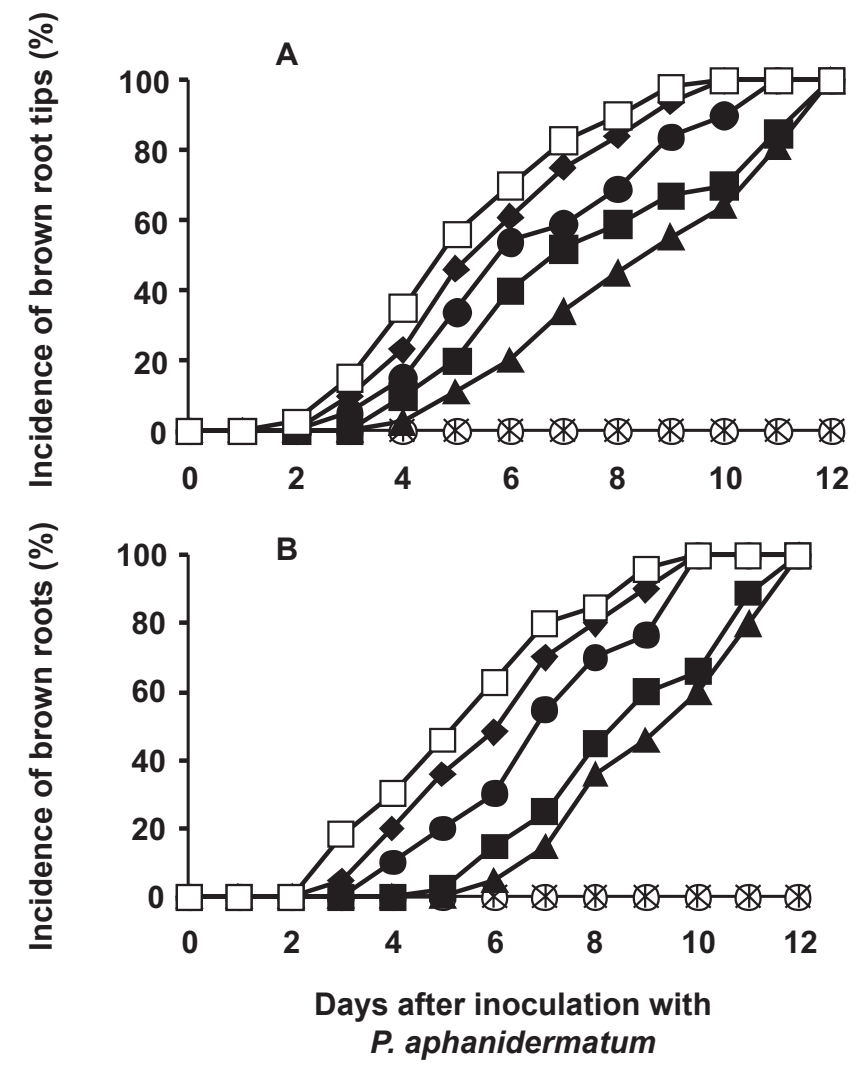

FIGURE 2 - A. Progress curves for percent brown root tips and B. percent brown roots in sweet peppers grown in single-plant hydroponic units in which the nutrient solution was $23^{\circ} \mathrm{C}$ and increased to $33^{\circ} \mathrm{C}$ for $0-144 \mathrm{~h}$ immediately before the roots were inoculated with Pythium aphanidermatum, or was not increased in control plants that were not inoculated. Symbols indicate treatments in terms of hours at $33^{\circ} \mathrm{C}$ and inoculation or no inoculation with $P$. aphanidermatum as follows: $\circ 0 \mathrm{~h}-$ Pythium; $\boldsymbol{\Delta} 0 \mathrm{~h}+$ Pythium; $\mathrm{X} 1-126 \mathrm{~h}-$ Pythium; $-9 \mathrm{~h}+$ Pythium; $24 \mathrm{~h}+$ Pythium; $72 \mathrm{~h}+$ Pythium; $\square 144 \mathrm{~h}+$ Pythium. general root browning. However, disease progressed approximately 1 day earlier in roots that were treated at $33^{\circ} \mathrm{C}$ for $9 \mathrm{~h}$ before inoculation compared with those that were not exposed to $33^{\circ} \mathrm{C}(0 \mathrm{~h})$ before inoculation (Figures 2A and 2B). The disease progress curves further show that root tip browning and expansive root browning developed progressively earlier as the duration of preinoculation high temperature was increased from 9 to $144 \mathrm{~h}$. Curves for roots treated at $33^{\circ} \mathrm{C}$ for 12 and $18 \mathrm{~h}$, $48 \mathrm{~h}$, or 96 and $120 \mathrm{~h}$, respectively (data not shown) fell between those for 9 and 24 h, 24 and 72 h, and 72 and 144 h. Curves for roots exposed to $33^{\circ} \mathrm{C}$ for various periods before inoculation were similar in shape and slope to those of inoculated plants maintained continuously at $23^{\circ} \mathrm{C}\left(0 \mathrm{~h}\right.$ at $\left.33^{\circ} \mathrm{C}\right)$, regardless of the duration of exposure to $33^{\circ} \mathrm{C}$ and of whether disease was expressed in terms of brown root tips or expansive root browning. Multiple comparison of the slopes of the regression lines for values from $20 \%$ to $80 \%$ disease severity did not reveal significant differences among treatments $(\mathrm{P}=0.05)$. The incidence of brown root tips and severity of expansive browning each reached $50 \%$ about 4.5 days earlier in plants treated at $33^{\circ} \mathrm{C}$ for $144 \mathrm{~h}$ compared to inoculated plants that were not exposed to $33^{\circ} \mathrm{C}$ (i.e. the $0 \mathrm{~h}$ treatment; Figures $3 \mathrm{~A}$ B). Precocious responses in terms of time to $50 \%$ disease were especially marked following 9 to $24 \mathrm{~h}$ of high rootzone temperature, whereas further increases up to $144 \mathrm{~h}$ exerted comparatively minor additional effects. Curves for root tip browning and expansive root browning following 168,192 , or $216 \mathrm{~h}$ of high root-zone temperature did not differ significantly from those that followed $144 \mathrm{~h}$ of high temperature.

Delayed inoculation as a factor affecting relationships of pre-inoculation high temperature and root rot

No browning symptoms developed in non-inoculated plants with roots that were not exposed to $33^{\circ} \mathrm{C}$ (i.e. maintained continuously at $23^{\circ} \mathrm{C}$ ) or in those exposed to the high temperature and assessed at $0,72,144$, or $216 \mathrm{~h}$ later (data not shown). In inoculated plants not treated at $33^{\circ} \mathrm{C}$ the incidence of brown root tips increased linearly beginning at 4 days after inoculation and reached 50\% and $100 \%$ at 8 and 11 days, respectively (Figure 4A). By comparison, root tip browning developed about 2 days earlier in plants that were inoculated immediately $(0 \mathrm{~h})$ following the high temperature treatment $\left(33^{\circ} \mathrm{C}\right.$ for $72 \mathrm{~h}$ ), such that a few tips were brown at 2 days after inoculation, $50 \%$ were brown at 5.5 days, and $100 \%$ were brown at 9 days. In plants inoculated at $72 \mathrm{~h}$ after the high temperature treatment, root tip browning developed after approximately the same interval following inoculation and in a similar pattern to that found for plants inoculated immediately $(0 \mathrm{~h})$ following the high temperature episode. However, when inoculation was delayed until $144 \mathrm{~h}$ and 216 $\mathrm{h}$ after the high temperature treatment the progress curves for root tip browning were delayed approximately 1.0 and 

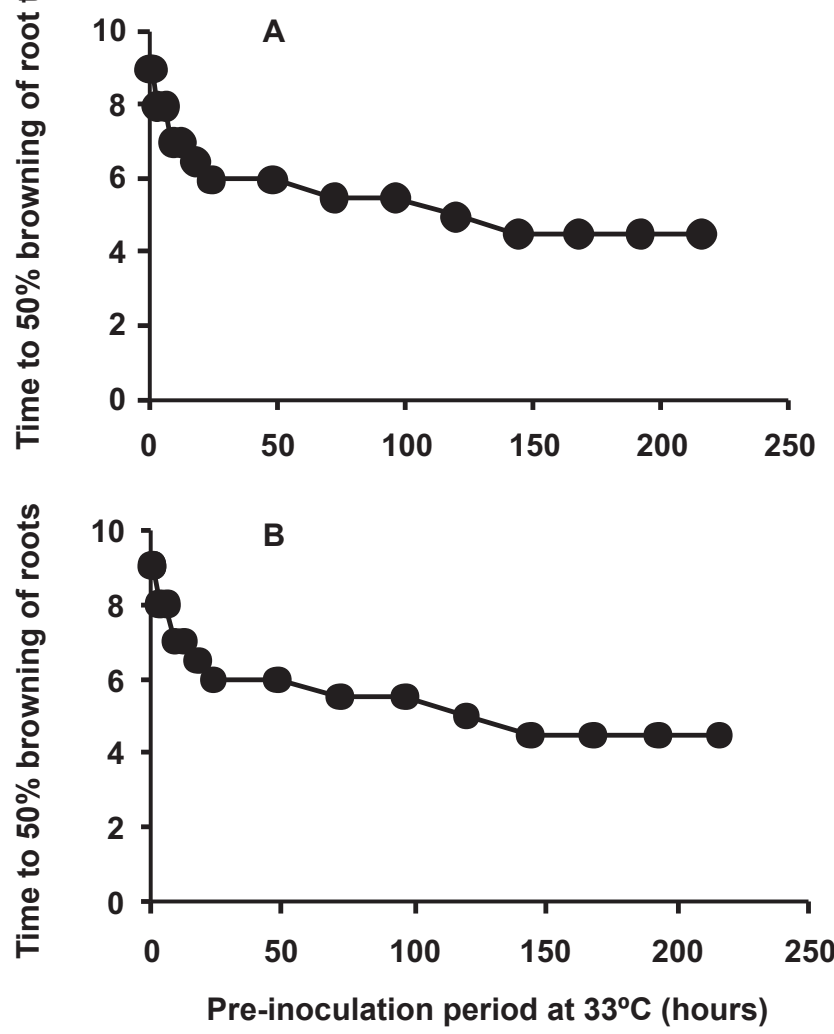

FIGURE 3 - A. Time to $50 \%$ incidence of brown root tips and B. to $50 \%$ root browning (B) in sweet peppers grown in singleplant hydroponic units in which the nutrient solution was $23^{\circ} \mathrm{C}$ and increased to $33^{\circ} \mathrm{C}$ for $0-216 \mathrm{~h}$ immediately before the roots were inoculated with Pythium aphanidermatum.

2.0 days following inoculation, respectively, compared with plants inoculated immediately after the high temperature treatment, but nonetheless earlier than in inoculated plants that were not exposed to $33^{\circ} \mathrm{C}$ (i.e. maintained continuously at $23^{\circ} \mathrm{C}$ ).

Expansive browning of roots of the inoculated plants that were not treated at $33^{\circ} \mathrm{C}$ (i.e. maintained continuously at $23^{\circ} \mathrm{C}$ ) increased almost linearly from 0 to $100 \%$ between 4 and 11 days after inoculation (Figure 4B). Root browning developed about 2 days earlier, however, in roots that were treated at high temperature and immediately inoculated. Progress of browning following high temperature treatment was progressively less precocious when root inoculation was delayed for 72,144 , and $216 \mathrm{~h}$ following the high temperature treatment (Figure 4B). In plants inoculated at $0,72,144$, and $216 \mathrm{~h}$ after high temperature treatment, $50 \%$ of the roots were brown by $6,7,7$, and 8 days after inoculation compared to 10 days for inoculated plants that were not treated at $33^{\circ} \mathrm{C}$.

\section{DISCUSSION}

The observations demonstrate that a single period of high root-zone temperature $\left(33^{\circ} \mathrm{C}\right)$ of $9 \mathrm{~h}$ or longer predisposes vegetative pepper plants to precocious root tip browning and expansive root browning caused by $P$. aphanidermatum. Because the roots were exposed to high temperature only before inoculation, the observed precocious browning of the roots was mediated entirely through host responses to the high temperature episodes. All phases of disease development including root infection by the zoospores, biotrophic colonization of the roots by hyphae of the pathogen, and the necrotrophic phase when the roots turned brown (Sutton et al., 2006) developed while the temperature of the root zone was moderate (near $23^{\circ} \mathrm{C}$ ),

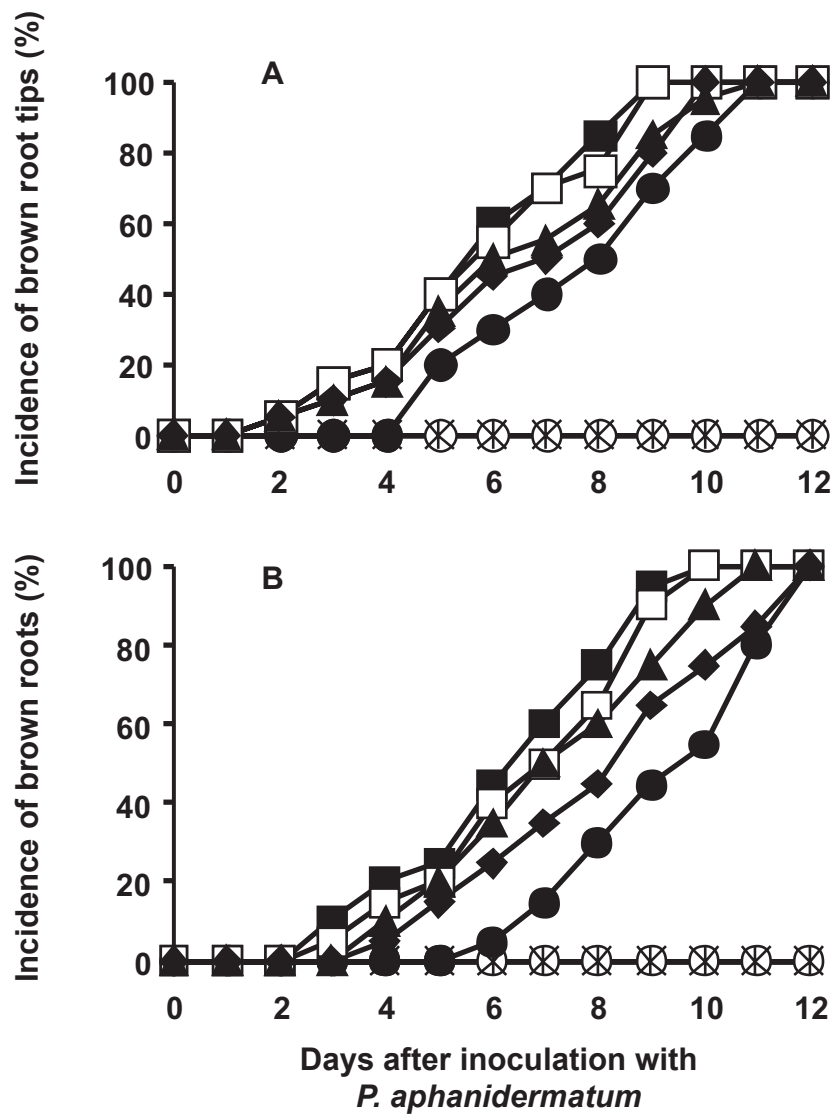

FIGURE 4 - A. Progress curves for percent brown root tips; B. and percent brown roots in sweet peppers that were grown in single-plant hydroponic units at $23^{\circ} \mathrm{C}$ and inoculated with Pythium aphanidermatum at $0-216 \mathrm{~h}$ after a standard episode of high nutrient solution temperature $\left(33^{\circ} \mathrm{C}\right.$ for $\left.72 \mathrm{~h}\right)$, or were not treated at the high temperature and were then inoculated or not inoculated. Symbols indicate treatments in terms of high temperature treatment or not, hours at $23^{\circ} \mathrm{C}$ following treatment at $33^{\circ} \mathrm{C}$ and inoculation with $P$. aphanidermatum as follows: $\odot$ no treatment, $0 \mathrm{~h}-$ Pythium; - no treatment, $0 \mathrm{~h}+$ Pythium; X 1-216 h - Pythium; - treatment, $0 \mathrm{~h}+$ Pythium; $\square$ treatment, $72 \mathrm{~h}+$ Pythium; $\boldsymbol{\Delta}$ treatment, $144 \mathrm{~h}+$ Pythium $;$ treatment, $216 \mathrm{~h}+$ Pythium.

Tropical Plant Pathology 34 (6) November - December 2009 
Relationships of pre-inoculation high temperature to root browning...

thus precluding the possibility of any direct influence of high temperature on disease development.

While pre-inoculation high temperature evoked precocious browning of the roots following inoculation with $P$. aphanidermatum, the rate of increase in brown roots was largely unaffected. As indicated by the slopes of the browning curves, the rate of browning was similar for all pre-inoculation high temperature treatments, including the inoculated control plants that were not exposed to high temperature. In each instance browning symptoms increased from near zero to $100 \%$ within 7 to 8 days. The browning curves may have arisen entirely from the zoospores used to initiate disease, in which case root rot development was monocyclic. Any zoospores produced in the root zones of hydroponic units during the brief period of disease increase would almost certainly have been immobilized, and thus inactivated, by the incessant turbulence produced by air bubbled into the nutrient solution to maintain dissolved oxygen levels (Sutton et al., 2006). Taken together, the data indicate that high pre-inoculation temperature of the root-zone shortens the biotrophic phase and thus advances the necrotrophic phase of root rot, but has little effect on the rate of expansive root browning once the necrotrophic phase is initiated.

The quantitative relationship found between the duration of high pre-inoculation temperature and the time required following inoculation for the roots to turn brown exhibited three major attributes: a minimum duration threshold (approximately 6-9 h) below which no precocious response was detected, an intermediate range of 9-144 h in which increasing duration of high temperature evoked progressively earlier root browning, and a maximum duration threshold of 144-168 h which, if exceeded, did not further affect the time of root browning. Among the durations of pre-inoculation high temperature evaluated, periods of 144-216 $\mathrm{h}$ resulted in the most precocious and overlapping curves in which the roots turned brown approximately 4 days before those of inoculated control plants maintained continuously at $23^{\circ} \mathrm{C}$. As indicated by the curves for times from inoculation to $50 \%$ root browning (Figure $3 \mathrm{~B}$ ), the precocious responses of root browning to incremental increases in duration of high temperature were more pronounced for periods of high temperature in the range of 6-24 h compared to 24-144 h. The shapes of the curves suggest that a saturation phenomenon was involved in the host response to lengthening episodes of high temperature. Possible contributions to precocious root browning of rootzone temperatures during periods of warming and cooling of the nutrient solution were not determined. A quantitative relationship between duration of pre-inoculation high temperature $\left(35-45^{\circ} \mathrm{C}\right)$ and disease severity was also reported for black spruce needles inoculated with Botrytis cinerea (Zhang \& Sutton, 1994).

The observed persistence of predisposition to root browning evoked by high root-zone temperature indicated that the predisposition to $P$. aphanidermatum was somehow "memorized" by the peppers. From the data of precocious root browning, predisposition was "memorized" for at least $216 \mathrm{~h}$ (9 days) following a high temperature episode of $72 \mathrm{~h}$. More prolonged persistence was also possible given that the roots turned brown at least a day earlier in plants inoculated at $216 \mathrm{~h}$ compared to similar plants that were not exposed to high temperature. Intensity of pre-disposition was high for at least $72 \mathrm{~h}$ based on the similar precociousness of root browning when roots were inoculated at 0 or $72 \mathrm{~h}$ after high temperature treatment, and moderately high for $144 \mathrm{~h}$ based on the substantially precocious browning curve obtained. The progressive decline in precociousness of browning when inoculation was delayed for more than $72 \mathrm{~h}$ suggested that the roots were slowly recovering from effects of high temperature treatment.

The observed predisposition to root browning was not attributed to oxygen depletion in the nutrient solution since the level of dissolved oxygen in the aerated nutrient solutions was maintained between 5 and $7 \mathrm{mg} \mathrm{O}_{2} \mathrm{~L}^{-1}$ solution and did not differ significantly when the solution temperature was $33^{\circ} \mathrm{C}$ compared with $23^{\circ} \mathrm{C}$. However, the general decline in levels of dissolved oxygen with increasing temperature when nutrient solutions are not well aerated or oxygenated may enhance host predisposition to root rot, and so may be a factor in hydroponic pepper crops. Increased rates of development of root rot caused by $P$. aphanidermatum and other Pythium spp. when the temperature was high and concentration of dissolved oxygen was reduced could not be attributed entirely to host predisposition (Chérif et al., 2004). Many investigators reported greater severity of Pythium root rot when temperatures were high (e.g. $\left.27-35^{\circ} \mathrm{C}\right)$ than when moderate (e.g. $20-25^{\circ} \mathrm{C}$ ), but it was unclear whether the effects could be ascribed exclusively to high temperature or also to reduced oxygen levels, and whether the effects were mediated through the host or pathogen separately or in combination (Sutton et al., 2006). In the present study, host predisposition is attributed to high temperature but not to reduced oxygen levels in the nutrient solution during the pre-inoculation high temperature treatments.

Stress responses of the peppers to the high temperature treatments possibly played a role in the predisposition of the roots to browning. High temperature (heat) stress is a function of the rate of temperature increase and the intensity (in degrees) and duration of the stress-level temperature (Wahid et al., 2007). The findings that predisposition evoked by high temperature increased with treatment duration were consistent with reported plant responses to stress-level temperatures (Wahid et al., 2007) and with the notion that there is a relationship between stress responses and predisposition. The intensity of the high temperature treatments $\left(33^{\circ} \mathrm{C}\right)$ exceeded temperatures quoted as optimal or near-optimal for vegetative growth and fruit production in peppers (Andrews, 1984; Dodd et al., 2000) and so may have been sufficient to induce mild stress responses. Common responses of plants to moderate temperature stress include alterations in the homeostasis, stability, 
biosynthesis and compartmentalization of hormones and increased fluidity and permeability of cellular membranes (Wahid et al., 2007). When temperature is high, levels of the stress hormones abscissic acid (ABA) and ethylene generally increase, and production of cytokinins, which act to delay senescence, decrease (Taiz \& Zeiger 2006; Wahid et al., 2007). In response to stress, ABA promotes senescence and stimulates the production of ethylene, which regulates numerous growth and developmental processes in plants and accelerates tissue senescence (Taiz \& Zeiger, 2006; Wahid et al., 2007). In a study with explants of pepper (Capsicum annuum), ethylene production was greater at $34^{\circ} \mathrm{C}$ than at 25, 42 and $48^{\circ} \mathrm{C}$ (Aloni et al., 1994). Huberman et al. (1997) reported a positive correlation between high temperature and the level of 1-amino-cyclopropane-1-carboxylic acid, a precursor of ethylene biosynthesis, in the pepper genus Piper nigrum. Taken together, the physiological responses of roots to high temperature stress are similar to physiological changes that occur during senescence (Taiz \& Zeiger, 2006). It is plausible that physiological changes in the roots following high temperature treatment such as increased permeability of the cell membranes, enhanced leakage of ions and energy sources into the intercellular spaces, and reduced tissue resistance to the pathogen may have favored intensified root colonization by $P$. aphanidermatum during the biotrophic phase. In agreement with findings of OwenGoing et al. (2008), the pathogen was recovered from all portions of root systems within $12 \mathrm{~h}$ after the roots were inoculated, but densities of hyphae in the root tissues were not determined. To explain the precocious browning in predisposed roots, it is hypothesized that root browning develops as a function of colonization intensity of the roots by $P$. aphanidermatum.

Browning of pepper roots infected by $P$. aphanidermatum is associated with phenolic polymers that accumulate in the tissues and bind to the cell walls (Owen-Going et al., 2008; Sutton et al., 2003). Phenolic compounds in higher plants are derived at least in part from phenylalanine, a product of the shikimic acid pathway (Taiz \& Zeiger, 2006). Deamination of phenylalanine by phenylalanine ammonia lyase (PAL) yields transcinnamic acid and its phenylpropanoid derivatives which are important building blocks for more complex phenolic compounds. Taken together, available evidence indicates that $P$. aphanidermatum activates the shikimic acid and phenylpropanoid pathways and promotes biosynthesis of phenolic compounds in infected roots (Owen-Going, 2006). Elicitors of $P$. aphanidermatum and other pathogens were reported to increase PAL in cultured plant cells and protoplasts (Schnitzler \& Seitz 1989). A possible activator of the phenylpropanoid pathway, and thus a trigger for root browning, is the metabolite referred to as the $P$. aphanidermatum necrosis-inducing elicitor, or PaNie (Veit et al., 2001). Conditions that initiate or stimulate production of elicitors or other factors that trigger root browning, and thus the end of the biotrophic phase, are not understood.
It is suggested that intensified colonization of roots by $P$. aphanidermatum following high temperature predisposition mediates early synthesis of PaNie to thresholds sufficient to trigger precocious browning of the roots. The findings that pre-inoculation high temperature had little effect on the rate of root browning under constant moderate temperature $\left(23^{\circ} \mathrm{C}\right)$, and that browning increased continuously to about $100 \%$ in all treatments, may indicate that browning becomes autocatalytic once triggered.

The quantitative observations of high root-zone temperature in relation to root browning contribute further understanding of Pythium root rot epidemiology and have implications for rational management of the disease in commercial pepper crops. Based on our data, populations of predisposed but otherwise healthy peppers in hydroponic greenhouses are at risk of precocious and rapid root rot development should they become infected by $P$. aphanidermatum. The persistence of predisposition over at least 9 days has implications for pepper health management. For example, peppers exposed to high temperature as transplants could remain predisposed to root rot after they are transferred to production greenhouses. In another possible scenario, shortening of infection cycles of $P$. aphanidermatum on account of host predisposition may favor zoospore production and accelerate progress of root rot in commercial pepper crops, even during early stages of epidemics when rates of increase in root browning (i.e. slopes of browning curves) are comparatively low (OwenGoing, 2002). The observations of high temperature and pre-disposition provide a rational basis for estimating the risk of precocious disease increase and the available window of opportunity for taking preventative or remedial measures such as through the use of beneficial microbes (Corrêa \& Bettiol, 2009). Prediction of precocious disease could be further refined based on additional data, such as serial episodes of high temperature which might act cumulatively, additively or otherwise in predisposing pepper plants to root rot. However. the finding that a single episode of 6 to $9 \mathrm{~h}$ at $33^{\circ} \mathrm{C}$ is sufficient to predispose peppers to Pythium root rot underscores the importance of minimizing high temperature episodes for managing root health and promoting productivity of hydroponic pepper crops.

\section{ACKNOWLEDGEMENTS}

This research was supported by the Natural Sciences and Engineering Research Council of Canada and the Ontario Ministry of Agriculture, Food, and Rural Affairs.

\section{REFERENCES}

Aloni B, Karni L, Zaidman Z, Riov Y, Huberman M, Goren R (1994) The susceptibility of pepper (Capsicum annuum) to heat induced flower abscission: possible involvement of ethylene. Journal of Horticultural Science 69:923-928. 
Relationships of pre-inoculation high temperature to root browning...

Andrews J (1984) Peppers: The Domesticated Capsicums. Austin TX. University of Texas Press.

Chérif M, Tirilly Y, Bélanger RR (1997) Effect of oxygen concentration on plant growth, lipid peroxidation, and receptivity of tomato roots to Pythium $\mathrm{F}$ under hydroponic conditions. European Journal of Plant Pathology 103:255-264.

Colhoun J (1979) Predisposition by the environment. Pages 7596 In: Horsfall JG and. Cowling EB (Eds.) Plant Disease: An Advanced Treatise. Volume IV. How Pathogens Induce Disease. New York NY. Academic Press.

Corrêa EB, Bettiol W (2009) Controle da podridão de raiz e promoção de crescimento em hidroponia com bactérias. In: Bettiol W, Morandi MAB (Eds.) Biocontrole de doenças de plantas: uso e perspectivas. Jaguariúna SP. Embrapa Meio Ambiente.

Dodd IC, He J, Turnbull CGN, Lee SK, Critchley C (2000) The influence of supra-optimal root-zone temperatures on growth and stomatal conductance in Capsicum annuum L. Journal of Experimental Botany 51:239-248.

Gold SE, Stanghellini ME (1985) Effects of temperature on Pythium root rot of spinach under hydroponic conditions. Phytopathology 75:333-337.

Huberman M, Riov J, Aloni B, Goren R (1997) Role of ethylene biosynthesis and auxin content and transport in high temperatureinduced abscission of pepper reproductive organs. Journal of Plant Growth Regulation 16:129-135.

Jarvis WR (1992) Managing diseases in greenhouse crops. Saint Paul MN. APS Press.

Johnstone MB, Chatterton S, Sutton JC, Grodzinski B (2005) Net carbon gain and growth of bell peppers, Capsicum annuum L. 'Cubico' following root infection by Pythium aphanidermatum. Phytopathology 95:354-361.

Littrell RH, McCarter SM (1970) Effect of soil temperature on virulence of Pythium aphanidermatum and Pythium myriotylum to rye and tomato. Phytopathology 60:704-707.

Liu W, Sutton JC, Grodzinski B, Kloepper JW, Reddy MS (2007) Biological Control of Pythium Root Rot of Chrysanthemum in Small-scale Hydroponic Units. Phytoparasitica 35:159.

Martin FN, Loper JE (1999) Soilborne plant diseases caused by Pythium spp.: ecology, epidemiology, and prospects for biological control. Critical Reviews in Plant Sciences 18:111-181.

Owen-Going TN (2002) Etiology and epidemiology of Pythium root rot in bell pepper (Capsicum annuum L.) in commercial-scale and small-scale hydroponic systems. M.Sc. thesis, University of Guelph, Guelph, Ontario, Canada.

Owen-Going TN (2006) Quantitative investigations of phenolic compounds associated with root rot of hydroponic pepper (Capsicum annuum L.) caused by Pythium aphanidermatum (Edson) Fitzp. Ph.D. thesis. University of Guelph, Guelph, Ontario, Canada.
Owen-Going, TN, Beninger CW, Sutton JC, Hall JC (2008) Accumulation of phenolic compounds in plants and nutrient solution of hydroponically grown peppers inoculated with Pythium aphanidermatum. Canadian Journal of Plant Pathology 30:214-225

Owen-Going, TN, Sutton JC, Grodzinski B (2003) Relationships of Pythium isolates and sweet pepper plants in single-plant hydroponic units. Canadian Journal of Plant Pathology 25:155167.

Panova GG, Grote D, Kläring HP (2004) Population dynamics of Pythium aphanidermatum and response of tomato plants as affected by root-zone temperature. Journal of Plant Diseases and Protection 111:52-63.

Schnitzler JP, Seitz HU (1989) Rapid responses of cultured carrot cells and protoplasts to an elicitor from the cell wall of Pythium aphanidermatum (Edson) Fitzp. Zeitschrift für Naturforschung 44:1020-1028.

Sopher CR, Sutton JC (2008) Temperatura alta da solução nutritiva predispõe o pimentão a podridão radicular causada por Pythium. Summa Phytopathologica 34(Supl.):29.

Sutton JC, Owen-Going, N, Sopher CR, Hall JC (2003) Interactive effects of Pythium aphanidermatum and allelopathic phenolics accelerate root rot epidemics in hydroponic peppers (Capsicum annuиm L.). Fitopatologia Brasileira (Supl.) 28:363.

Sutton JC, Sopher CR, Owen-Going TN, Liu W, Grodzinski B, Hall JC, Benchimol RL (2006) Etiology and epidemiology of Pythium root rot in hydroponic crops: current knowledge and perspectives. Summa Phytopathologica 32:307-321.

Taiz L, Zeiger E (2006) Plant Physiology. Sunderland MA. Sinhauer Associates Inc. Publishers.

Thomson TB, Athow KL, Laviolette FA (1971) The effect of temperature on the pathogenicity of Pythium aphanidermatum, $P$. debaryanum, and P. ultimum. Phytopathology 61:933-935.

Van der Platts-Niterink AJ. (1981) Monograph of the genus Pythium. Baarn, Centraalbureau voor Schimmelcultures. pp. 3437.

Veit S, Worle JM, Nurnberger T, Koch W, Seitz HU (2001) A novel protein elicitor (PaNie) from Pythium aphanidermatum induces multiple defense responses in carrot, Arabidopsis, and tobacco. Plant Physiology 127:832-841.

Wahid A, Gelani S, Ashraf M, Foolad MR (2007) Heat tolerance in plants: an overview. Environmental and Experimental Botany 61:199-223.

Zhang PG, Sutton JC (1994) High temperature, darkness, and drought predispose black spruce seedlings to gray mold. Canadian Journal of Botany 72:135-142.

Zheng J, Sutton JC, Yu H. (2000) Interactions among Pythium aphanidermatum, roots, root mucilage, and microbial agents in hydroponic cucumbers. Canadian Journal of Plant Pathology $22: 368-379$ 